\title{
Scalp Psoriasis: Systematic Review Comparing Topical Treatments and Placebo
}

\author{
Regina Jales', Sérgio Hirata², Álvaro Attalah³, Danúbia Sá-Caputo4, Adriano Arnóbio5, \\ Éric Heleno Frederico ${ }^{5}$, Mario Bernardo-Filho ${ }^{5}$, Humberto Saconato ${ }^{1}$ \\ ${ }^{1}$ Departamento de Clínica Médica, Hospital Universitário Onofre Lopes, Universidade Federal do Rio Grande do \\ Norte, Natal, Brazil \\ ${ }^{2}$ Departamento de Dermatologia, Hospital São Paulo, Universidade Federal de São Paulo, São Paulo, Brazil \\ ${ }^{3}$ Departamento de Medicina Interna, Hospital São Paulo, Universidade Federal de São Paulo, São Paulo, Brazil \\ ${ }^{4}$ Programa de Pós-Graduação em Fisiopatologia Clínica e Experimental, Universidade do Estado do Rio de \\ Janeiro, Rio de Janeiro, Brazil \\ ${ }^{5}$ Departamento de Biofísica e Biometria, Universidade do Estado do Rio de Janeiro, Rio de Janeiro, Brazil \\ Email: bernardofilhom@gmail.com
}

Received 26 May 2015; accepted 26 June 2015; published 29 June 2015

Copyright (C) 2015 by authors and Scientific Research Publishing Inc.

This work is licensed under the Creative Commons Attribution International License (CC BY).

http://creativecommons.org/licenses/by/4.0/

(c) (†) Open Access

\section{Abstract}

Patients with scalp psoriasis suffered from a lower quality of life relating to the highly visible site of their psoriatic lesions. In consequence this fact stimulates investigations involving treatments of this dermatologic disease. The aim of this review is to evaluate the topical treatments for scalp psoriasis compared with placebos. Methods: A systematic review was performed using searches in the database LILACS, MEDLINE, Cochrane Library, and Embase. As selection criteria were chosen eligible publications involving randomized controlled trials, patients with scalp psoriasis diagnosed clinically or by biopsy, interventions with topical treatments for scalp psoriasis compared with placebo. Outcome related to the reduction in severity of psoriasis of the scalp, assessed by physicians and patients, and assessment of adverse effects that required discontinuation of treatment. The results have shown that the patients were aged 12 to 97 years, including 3441 patients. Ten of the fifteen studies included reported gender data. Patients were mostly female. Twelve studies were about psoriasis's severity. These studies in which the severity has been described, the classification of severity was mild ( 0 study), mild to moderate (1 study), moderate to severe (11 studies) and severe ( 0 study). In conclusion, topical corticosteroids, calcipotriol, ciclopirox olamine and associations between them are effective in the treatment of scalp psoriasis. Clobetasol propionate $(0.05 \%)$ was the most effective active ingredient in several vehicles in the induction treatment of scalp psoriasis. 


\section{Keywords}

\section{Scalp Psoriasis, Topical Treatments, Placebo, Topical Corticosteroids}

\section{Introduction}

Psoriasis is a hereditary disorder that affects 3\% of the population worldwide [1]-[3]. There are two common ages for the onset of psoriasis. The first is around 21 years and the second at approximately 50 years [4] [5]. The most frequent type is psoriasis vulgaris, which appears as chronic, erythematous (reddish), and scaling skin lesions [6]. Clinical presentation varies from those with only a few localized lesions to those with generalized skin involvement [4].

There is evidence indicating that interaction between genes and certain environmental factors is an important cause of this disease [7]. Inflammatory cytokines such as tumor necrosis factor alpha, interferon gamma, and other type 1 cytokines also play an important role in the pathogenesis of psoriasis [8]. Many drugs that are used to treat other clinical conditions have also been reported to be responsible for the onset or exacerbation of psoriasis [9]. Among these drugs are lithium salts, antimalarials, beta-blocking agents, non-steroidal anti-inflammatory drugs (NSAIDS), angiotensin-converting enzyme (ACE) inhibitors, and the withdrawal of corticosteroids [10] [11].

Many clinical variants to the psoriasis are described, such as psoriasis vulgaris, guttate psoriasis (drops psoriasis), erythrodermic psoriasis (red psoriasis) and pustular psoriasis [11] [12]. The scalp is one of the most commonly affected parts of the body in people with psoriasis, and the frequency of involvement increases with the duration of the disease [13]. It may be part of generalized psoriasis or coexist with isolated plaques, or the scalp may be the only site involved. Signs and symptoms of scalp psoriasis vary significantly in different people, but pruritus, scaling and cosmetic embarrassment are often present [14] [15]. Because sensitive facial skin is so near the scalp, the use of potentially irritating topical treatments may be limited. Even so, the specific challenges of scalp psoriasis are often neglected in treatment guidelines [15] [16].

Scalp psoriasis can occasionally be confused with seborrhoeic dermatitis affecting the scalp [17]. Seborrhoeic dermatitis is another inflammatory condition which commonly affects the whole of the scalp resulting in mild inflammation and dandruff [17]. Psoriasis on the other hand is usually well-demarcated and has a coarser scale, but early diffuse psoriasis of the scalp can sometimes look very similar to seborrhoeic dermatitis. Sometimes a scalp biopsy may help [18] [19]. Those with psoriasis may also suffer from psychological distress, especially as a result of stigmatization and self-consciousness, so relatively high rates of depression have been reported [20].

The Psoriasis Area and Severity Index (PASI) is one of the most frequently used instruments to evaluate the severity of the disease and its response to different treatments, and its use is based on the extension and severity of the impact on the skin's surface [21] [22].

Relevant aspects of psoriasis that affect the person with this disease are evaluated using a variety of instruments, including the Psoriasis Disability Index (PDI) [23], Dermatology Quality of Life Index (DLQI) [24], the Psoriasis Symptom Assessment [25], and the Itching Scale [26]. The Physician Global Assessment is a tool to evaluate the psoriatic plaques [27]. This is a seven-point scale, with 7 being clear and 6 almost clear, 5 mild, 4 mild to moderate, 3 moderate, 2 moderately severe and 1 being severe psoriasis.

The aim of this review is to evaluate the topical treatments for scalp psoriasis compared with placebos.

\section{Material and Methods}

\subsection{Keywords and Searches in the Databases}

The keywords, psoriasis, scalp psoriasis and topical treatment were searched. The searches for identification of the publications used in this study were in Pubmed, Embase, The Cochrane Skin Group Specialised Register and in The Cochrane Central Register of Controlled Trials (CENTRAL) in The Cochrane Library. PubMed was searched from 2005 to august 2011. EMBASE, searched from 2010 to August 2011, LILACS (Latin American and Caribbean Health Science Information database, from 1982 to August 2011. The Salford Database of Psoriasis trials was searched up to August 2011. 


\subsection{Inclusion Criteria to Select Publications in This Investigation}

Concerning to the types of studies, only randomised controlled trials (RCTs) were included. The Participants of these studies had the diagnosis of scalp psoriasis, according to clinical or biopsy findings used by authors of primary studies, for example: the classical history, symptoms and signs and typical histopathologic features. The types of interventions were any comparisons of local therapies for scalp psoriasis and placebo, such as, Corticosteroids plus calcipotriol versus placebo, Calcipotriol versus placebo, Corticosteroids versus placebo, Ciclopirox olamine versus placebo, among others. In the studies the outcome measures were Primary outcomes (Reduction in clinician-assessed severity, Improvement in quality of life, Adverse events requiring withdrawal of the treatment such as serious allergic reactions) and Secondary outcomes (Subjective reduction in severity of psoriasis, Minor adverse events not requiring withdrawal of the treatment like rash, itching, Time free of disease, duration of response, measured by the proportion of participants relapsing to baseline scores during continued treatment or following discontinuation of treatment.

\subsection{Exclusion Criteria to Select Publications in This Investigation}

Quasi-randomized studies were not considered for inclusion. Papers published in other languages than in English were excluded.

\subsection{PRISMA Flowchart Involving the Steps in Selecting Full}

A flowchart, based in the PRISMA analysis [28], was done to show the steps in the selection of the full papers analyzed in this revision.

\subsection{Data Analysis}

Data was not comparable and therefore statistical pooling not appropriate with the result that the findings of this review were summarized in a narrative form.

\section{Results}

The electronic search found in PubMed 239 articles, in Embase, 39 articles and in the Cochrane Library, 125 articles. No article was found in the search of LILACS. Fifteen placebo-controlled studies were selected. The flowchart used in the selection of the papers discussed in this review is show in Figure 1.

The 15 studies included 3441 patients. The patient age was between 12 and 97 years old. Gender data were mentioned in 10 of the 15 studies included (66\%). Patients were mostly female (1934 women and 1691 men). Twelve studies have discussed about the severity of psoriasis. In these studies that the severity has been described, the classification of severity was mild ( 0 study), mild to moderate (one study), moderate to severe (11 studies) and severe (0 trial). However, four studies did not provide sufficient information to assess the clinical severity. The evaluation score most widely used to assess the clinical severity was the GSS-TSS (global-total severity score). Quality of life was also mentioned.

The duration of treatment ranged from two weeks to two months. The evaluation included Individual signs (erythema, scaling, and thickening) and Total score or global severity (TSS or GSS).

Concerning to the randomized controlled trials, among the fifteen selected publications, 8 studies (53\%) reported clearly the method used for randomization and 3 studies (20\%) used the computer randomization. Related to the anthropometric characteristics of participants used in the studies selected, as the age and gender, six studies (40\%) provided data regarding age, gender and characteristics of clinical patients. Eight studies (53\%) provided incomplete data. Eight studies were excluded. One study was not considered due to it did not provide data properly. Seven studies were excluded because there was no comparison with placebo.

In Table 1 are shown the selected publications, the treatments suggested involving medication and placebo, and the conclusion of the studies.

\section{Discussion}

Van Voorhees and Fried, 2009 [44] have pointed out that the involvement of the scalp in patient with psoriasis is frequent. Due to the greater exposure to the environmental, it has a considerable effect on the quality of life of 


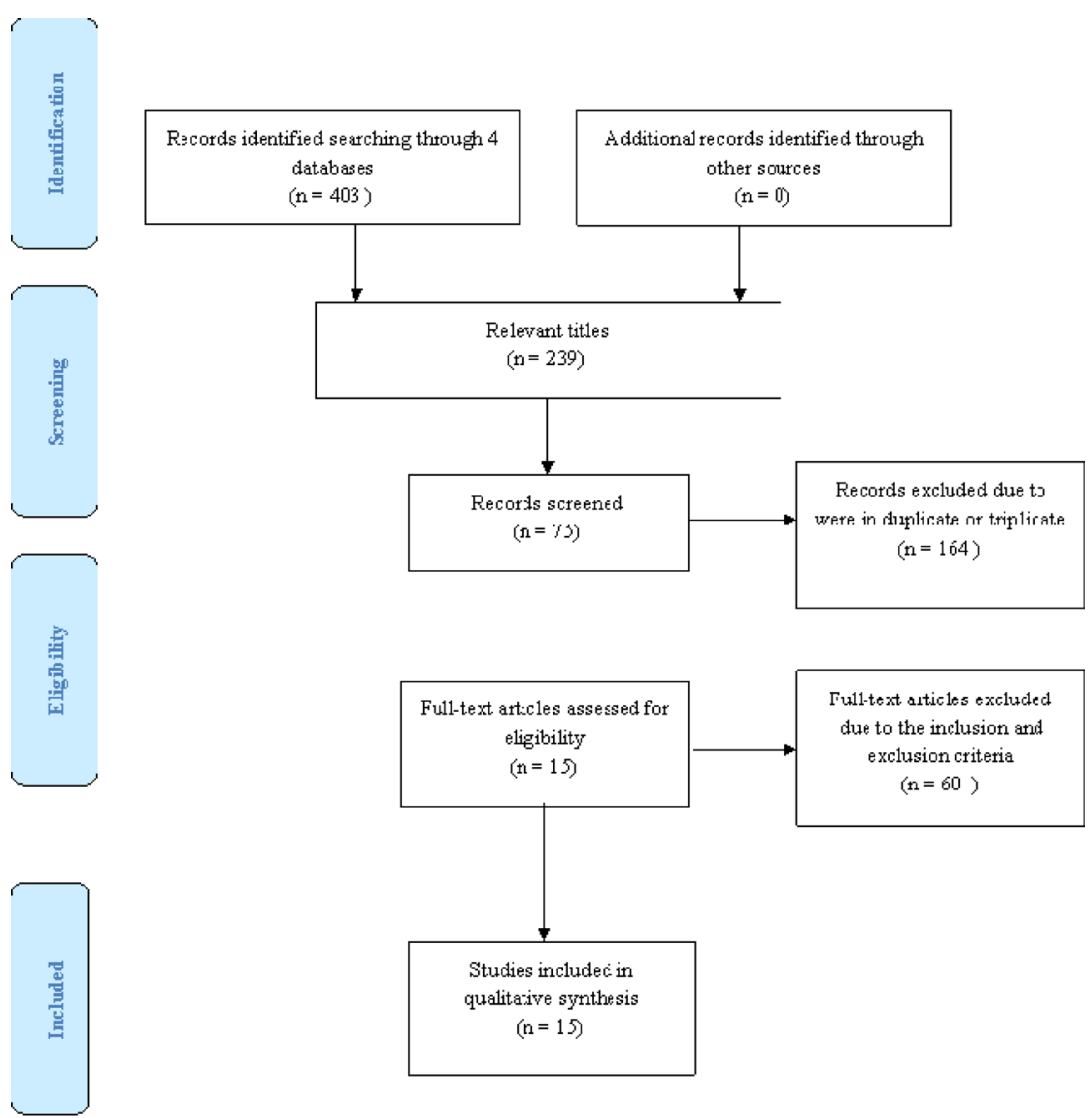

Figure 1. Flowchart indicating the steps to select the papers analyzed in this revision.

the patient. In this case, nevertheless, this fact must be discussed, due to the published studies rarely use tools to address these issues. Zampieron et al., 2015 [45] have also reported that patients with scalp psoriasis suffered from a lower quality of life relating to the highly visible site of their psoriatic lesions. In consequence this fact stimulates investigations with this dermatologic disease, as it is presented in our work.

Firstly 403 papers were found in the databases that were searched. However, the analysis of the available papers used in this review included only 15 randomized controlled trials (see flowchart in Figure 1) due to the inclusion and exclusion criteria use.

The number of participants with scalp psoriasis with topical treatment in the publications is more than three thousand. The selected papers involve a total of 3441 patients. Each of the studies utilized a comparison with a placebo, and the results of active ingredients were found to be more statistically significant than the placebos.

Many topical treatments, such as corticosteroids, calcipotriol, coal tar, salicylic acid are used for scalp psoriasis [46]. But, it is necessary to verify that there are few adequately controlled investigations that support the effectiveness of the suggested topical managements.

On the basis of the findings of this review, it was found that the best results were obtained with the use of clobetasol propionate in different vehicles (solution, foam and lotion) [29] [30]. When the placebo was compared to calcipotriol, there were better results with calcipotriol [47]-[49]; however, the magnitude of the effect was lower than in relation to clobetasol and It was similar to other corticosteroids, such as valerate of betamethasone, ancinonide, halcinonide, and fluocinolone acetonide. The opposite was observed for psoriasis on the body, which is described a greater efficiency in the association between calcipotriol and betamethasone dipropionate [50]. This study found no effect in terms of the overall gain in response to treatment in cases of psoriasis of the scalp. In Table 1, it is possible finding suitable information about the different formulations used to treat scalp psoriasis and the type of vehicle.

Characteristically, psoriasis is recurrent over years, and maintenance of the controlled disease, is a clinical challenge [51]. This fact is also true for scalp psoriasis. In this study, Meredith and Ormerod, 2012 [51] reported 
Table 1. Selected publications, the treatments and conclusion of the studies.

\begin{tabular}{|c|c|c|c|}
\hline References & $\begin{array}{c}\text { Type of } \\
\text { application }\end{array}$ & Treatment & Conclusion \\
\hline $\begin{array}{l}\text { Sofen et al., } 2011 \\
\text { [29] }\end{array}$ & Spray & $\begin{array}{l}\text { Clobetasol propionate } \\
\text { and placebo }\end{array}$ & $\begin{array}{l}\text { Treatment for up to four weeks is effective and well tolerated for } \\
\text { moderate-to-severe plaque psoriasis of the scalp. }\end{array}$ \\
\hline $\begin{array}{l}\text { Olsen et al., } 1991 \\
\quad[30]\end{array}$ & Ointment & $\begin{array}{l}\text { Clobetasol propionate } \\
\text { and placebo }\end{array}$ & $\begin{array}{l}\text { Clobetasol propionate } 0.05 \% \text { scalp application appears } \\
\text { to be a safe and an effective treatment for scalp psoriasis. }\end{array}$ \\
\hline $\begin{array}{l}\text { Jarratt et al., } 2004 \\
\text { [31] }\end{array}$ & Shampoo & $\begin{array}{l}\text { Clobetasol propionate } \\
\text { and placebo }\end{array}$ & $\begin{array}{l}\text { The shampoo formulation of clobetasol propionate is convenient } \\
\text { and efficacious and minimizes systemic exposure while being } \\
\text { efficient, safe and well-tolerated in the treatment of moderate } \\
\text { to severe scalp psoriasis. }\end{array}$ \\
\hline $\begin{array}{l}\text { Franz et al., } 2000 \\
\quad[32]\end{array}$ & Foam & $\begin{array}{l}\text { Clobetasol propionate } \\
\text { and placebo }\end{array}$ & $\begin{array}{l}\text { The results of the studies demonstrate that the enhancement of } \\
\text { absorption induced by the foam vehicle also leads to an increase in } \\
\text { efficacy. Data from } 188 \text { subjects show that those treated with } \\
\text { clobetasol propionate (CP) foam experienced greater psoriatic } \\
\text { improvement than subjects treated with a currently marketed } \\
\text { solution product. For each of the signs and symptoms of psoriasis, } \\
\text { as well as for the investigator's global assessment, CP foam } \\
\text { was found to be superior to CP solution. }\end{array}$ \\
\hline $\begin{array}{l}\text { Reygagne et al., } \\
2002 \text { [33] }\end{array}$ & Shampoo or gel & $\begin{array}{l}\text { Clobetasol propionate } \\
\text { and placebo }\end{array}$ & $\begin{array}{c}\text { After } 4 \text { weeks of treatment, clobetasol proprionate } 0.05 \% \text {, } \\
\text { shampoo was at least equivalent to the gel form and } \\
\text { superior to its vehicle. The two active treatments were } \\
\text { found to be equivalent safe. }\end{array}$ \\
\hline $\begin{array}{l}\text { Franz et al., } 1999 \\
\quad[34]\end{array}$ & Foam & $\begin{array}{c}\text { Betamethasone } \\
\text { valerate and placebo }\end{array}$ & $\begin{array}{l}\text { This formulation has increased efficacy in the treatment of scalp } \\
\text { psoriasis without an associated increase in toxicity. }\end{array}$ \\
\hline $\begin{array}{l}\text { Medansky and } \\
\text { Handler, } 1974 \text { [35] }\end{array}$ & Lotion & $\begin{array}{c}\text { Betamethasone } \\
\text { valerate and placebo }\end{array}$ & The lotion with betamethasone was more them the vehicle. \\
\hline & & $\begin{array}{c}\text { Betamethasone } \\
\text { valerate and placebo }\end{array}$ & \\
\hline $\begin{array}{l}\text { Tyring et al., } 2010 \\
{[36]}\end{array}$ & Ointment & $\begin{array}{l}\text { Calcipotriol and } \\
\text { betamethasone } \\
\text { dipropionate } \\
\text { with placebo }\end{array}$ & $\begin{array}{c}\text { Calcipotriol and betamethasone dipropionate was significantly } \\
\text { superior to placebo. } 71.9 \% \text { of patients had cleared ou minimal } \\
\text { disease after } 8 \text { weeks of treatment. }\end{array}$ \\
\hline Harris, 1972 [37] & $\begin{array}{l}\text { Lotion } \\
\text { (alcoholic) }\end{array}$ & $\begin{array}{l}\text { Valerate } \\
\text { betamethasone with } \\
\text { placebo }\end{array}$ & $\begin{array}{l}\text { Significant differences were found to exist in favor of betamethasone } \\
\text { valerate lotion } 0.1 \% \text { in lichenification, excoriation, inflammation, } \\
\text { scaling and pruritus than vehicle group. }\end{array}$ \\
\hline $\begin{array}{l}\text { Jemec et al., } 2008 \\
\text { [38] }\end{array}$ & ()$\left.^{*}\right)$ & $\begin{array}{l}\text { Two active ingredients } \\
\text { (calcipotriol and } \\
\text { betamethasone } \\
\text { dipropionate) } \\
\text { with each one active } \\
\text { ingredients separately } \\
\text { and with placebo }\end{array}$ & $\begin{array}{l}\text { The two active ingredients formula was superior to placebo } \\
\text { and both of the active ingredients separately. Adverse } \\
\text { effects were similar in the two compound group and } \\
\text { betamethasone group and significantly smaller than } \\
\text { calcipotriol group and placebo group. }\end{array}$ \\
\hline $\begin{array}{l}\text { Green et al., } 1994 \\
\text { [39] }\end{array}$ & Solution & Calcipotriol with placebo & $\begin{array}{l}\text { Calcipotriol was significantly superior to placebo in } \\
\text { reducing redness, thickness, scaliness and extent of psoriasis, } \\
\text { and in the patients' assessment in reducing scalp flaking and } \\
\text { itching. No statistically significant changes in blood } \\
\text { biochemistry were detected during the study, and the } \\
\text { solution was generally well tolerated. }\end{array}$ \\
\hline $\begin{array}{l}\text { Pauporte et al., } 2004 \\
{[40]}\end{array}$ & Topical oil & $\begin{array}{l}\text { Fluocinolone acetonide } \\
\text { with placebo }\end{array}$ & $\begin{array}{l}\text { It is shown that fluocinolone acetonide (FA) in an oil base } \\
\text { that aids in the softening of the skin and allows } \\
\text { penetration of the steroid into the stratum corneum, } \\
\text { is an effective treatment for psoriasis of the scalp. } \\
\text { This study also showed that the vehicle alone causes } \\
\text { an improvement in the signs of psoriasis, but that the } \\
\text { addition of } 0.1 \% \text { of the low potency steroid, FA } \\
\text { leads to a significantly better improvement. }\end{array}$ \\
\hline
\end{tabular}


Continued

\begin{tabular}{|c|c|c|c|}
\hline $\begin{array}{c}\text { Lepaw, } 1978 \\
{[41]}\end{array}$ & $\begin{array}{l}\text { Solution of } \\
\text { edetate } \\
\text { disodium, } \\
\text { polyethylene } \\
\text { glycol 300, } \\
\text { purified water } \\
\text { and butylated } \\
\text { hydroxytoluene. }\end{array}$ & $\begin{array}{c}\text { Halcinonide solution } \\
\text { with placebo }\end{array}$ & $\begin{array}{l}\text { The treatment was excellent in sixteen patients treated with } \\
\text { halcinonide and in one patient treated with placebo. In the } \\
\text { comparative evaluation halcinonide was superior in twenty-two } \\
\text { patients, the placebo was superior in four patients, and both drugs } \\
\text { were equally effective in one patient. There were no adverse } \\
\text { reactions due to halcinonide, but one patient experienced } \\
\text { pruritus with the placebo solution. }\end{array}$ \\
\hline $\begin{array}{c}\text { Ellis et al., } 1988 \\
{[42]}\end{array}$ & Lotion & $\begin{array}{l}\text { Amcinonide } \\
\text { with placebo }\end{array}$ & $\begin{array}{l}\text { Among the patients, overall improvements in psoriatic lesions was } \\
\text { seen in } 78 \% \text { amcinonide group and } 27 \% \text { of the placebo group. There } \\
\text { was no serious side effects attributtabe to this study. }\end{array}$ \\
\hline $\begin{array}{c}\text { Shuttleworth et al., } \\
1998 \text { [43] }\end{array}$ & Shampoo & $\begin{array}{l}\text { Ciclopirox olamine } \\
\text { and placebo }\end{array}$ & $\begin{array}{l}\text { For ciclopirox olamine only, there was significant }(\mathrm{P}<0.05) \\
\text { improvement over baseline for clinical assessment of overall } \\
\text { scalp psoriasis (day 29) and degree of scaling (days 8, } 15 \text { and 29) } \\
\text { and for patients' self-assessments of overall scalp psoriasis } \\
\text { (days } 15 \text { and 29) and scalp itching (day 15), but differences } \\
\text { from placebo were not significant. Ciclopirox olamine } \\
\text { tolerability and acceptability were good. }\end{array}$ \\
\hline
\end{tabular}

that it was not possible to assess recurrence rates because there was only a short period of follow up.

It is important to state that is often necessary to combine oral treatments and topicals, especially in severe cases of scalp psoriasis, there are, extensive or resistant to topical treatments. In these cases, some authors have pointed out the importance of medications, such as methotrexate, cyclosporine, acitretin, and treatment involving psoralen plus ultraviolet A (PUVA) [52]-[55].

Vergou et al., 2011 [56] have also suggested immunobiologicals, including infliximab, adalimumab and the etarnecept to be administered. For this class of drugs, a complete healing of the lesions and maintenance of the healing period of three years for adalimumab treatment has been described [57].

Psoriasis of the scalp, especially those cases classified as moderate to severe is associated with emotional and social disorders that affect the well-being of patients [58]. Despite this, few studies evaluate the emotional repercussions of this type of psoriasis patients. The National Psoriasis Foundation 2006 Benchmark Survey estimates that psoriasis has a moderate to large negative impact on quality of life (QoL) in approximately $75 \%$ of affected patients [59]. It is also noted that those patients are more likely to commit suicide when compared to those who do not have the disease [20] [60].

Adverse effects were found in 9 of 15 studies. Studies generally omit reporting adverse events. Due to the small sample of studies and the short follow-up period, ranging from two weeks to two months, the possibility of not detecting more serious adverse events or consequence of the chronic use of medications may be higher than they would be under other conditions.

\section{Conclusion}

In conclusion, this investigation demonstrates the efficacy of topical treatments for scalp psoriasis, such as corticosteroids, calcipotriol, ciclopirox olamine, and associations, when compared with placebos. Clobetasol propionate $(0.05 \%)$ was the most active ingredient, in various vehicles, in terms of the induction treatment of psoriasis of the scalp. However, due to the small clinical follow-up time of the studies, it was not possible to obtain data concerning the maintenance of the outcome or recurrence rates, so more research is needed in this area. It is important to consider that among the active principles used for the topical treatment of scalp psoriasis and compared with placebo, clobetasol propionate was the most effective, in all types of vehicle.

\section{Acknowledgements}

The authors thank the Conselho Nacional de Desenvolvimento Científico e Tecnológico (CNPq) (National Counsel of Technological and Scientific Development) for the support.

\section{Conflict of Interest}

There is no conflict of interest in this paper. 


\section{References}

[1] Huerta, C., Rivero, E. and Rodriguez, L.A. (2007) Incidence and Risk Factors for Psoriasis in the General Population. Archives of Dermatology, 143, 1559-1565. http://dx.doi.org/10.1001/archderm.143.12.1559

[2] Braathen, L.R., Botten, G. and Bjerkedal, T. (1989) Prevalence of Psoriasis in Norway. Acta Dermato-Venereologica, 142, 5-8.

[3] Nevitt, G.J. and Hutchinson, P.E. (1966) Psoriasis in the Community: Prevalence, Severity and Patients’ Beliefs and Attitudes towards the Disease. British Journal of Dermatology, 135, 533-537. http://dx.doi.org/10.1111/j.1365-2133.1996.tb03826.x

[4] Lomholt, G. (1963) Psoriasis: Prevalence, Spontaneous Course and Genetics. A Census Study on the Prevalence of Skin Disease on the Faroe Islands. G.E.C. Gad, Copenhagen.

[5] Zeljko-Penavic, J., Situm, M., Simic, D. and Vurnek-Zivkovic, M. (2010) Quality of Life in Psoriatic Patients and the Relationship between Type I and Type II Psoriasis. Collegium Antropologicum, 34, 195-198.

[6] Kastelan, M., Prpić-Massari, L. and Brajac, I. (2009) Apoptosis in Psoriasis. Acta Dermatovenerologica Croatica, 17, 182-186.

[7] Castelijns, F.A., Gerritsen, M.J., van Erp, P.E. and van de Kerkhof, P.C. (2000) Cell-Kinetic Evidence for Increased Recruitment of Cycling Epidermal Cells in Psoriasis: The Ratio of Histone and Ki-67 Antigen Expression Is Constant. Dermatology, 201, 105-110. http://dx.doi.org/10.1159/000018471

[8] Soler, D.C. and McCormick, T.S. (2011) The Dark Side of Regulatory T Cells in Psoriasis. Journal of Investigative Dermatolology, 131, 1785-1786. http://dx.doi.org/10.1038/jid.2011.200

[9] Chan, C.S., Van Voorhees, A.S., Lebwohl, M.G., Korman, N.J., Young, M., Bebo, B.F., et al. (2009) Treatment of Severe Scalp Psoriasis: From the Medical Board of the National Psoriasis Foundation. Journal of the American Academy of Dermatology, 60, 962-971. http://dx.doi.org/10.1016/j.jaad.2008.11.890

[10] Tracey, W. (2010) Psoriasis: Impact and Management of Moderate to Severe Disease. British Journal of Nursing, 19, 10-17. http://dx.doi.org/10.12968/bjon.2010.19.1.45905

[11] Rongioletti, F., Fiorucci, C. and Parodi, A. (2009) Psoriasis Induced or Aggravated by Drugs. Journal of Rheumatology, 83, 59-61. http://dx.doi.org/10.3899/jrheum.090227

[12] Telfer, N.R., Chalmers, R.J., Whale, K. and Colman, G. (1992) The Role of Streptococcal Infection in the Initiation of Guttate Psoriasis. Archives of Dermatolology, 128, 39-42. http://dx.doi.org/10.1001/archderm.1992.01680110049004

[13] Navarini, A.A. and Trueb, R.M. (2010) Psoriasis. Therapeutische Umschau, 67, 153-165. http://dx.doi.org/10.1024/0040-5930/a000029

[14] Van de Kerkhof, P.C., de Hoop, D., de Korte, J. and Kuipers, M.V. (1998) Scalp Psoriasis Clinical Presentations and Therapeutic Management. Dermatology, 197, 326-334. http://dx.doi.org/10.1159/000018026

[15] Farber, E.M. and Nall, M.L. (1974) The Natural History of Psoriasis in 5,600 Patients. Dermatologica, 148, 1-18. http://dx.doi.org/10.1159/000251595

[16] Ortonne, J., Chimenti, S., Luger, T., Puig, L., Reid, F. and Trüeb, R. (2009) Scalp Psoriasis: European Consensus on Grading and Treatment Algorithm. Journal of the European Academy of Dermatology \& Venereology, 23, 1435-1444. http://dx.doi.org/10.1111/j.1468-3083.2009.03372.x

[17] Kim, G.W., Jung, H.J., Ko, H.C., Kim, M.B., Lee, W.J., Lee, S.J., Kim, D.W., et al. (2011) Dermoscopy Can Be Useful in Differentiating Scalp Psoriasis from Seborrhoeic Dermatitis. British Journal of Dermatology, 164, 652-656. http://dx.doi.org/10.1111/j.1365-2133.2010.10180.x

[18] Mashaly, H.M., Masood, N.A. and Mohamed, A.S. (2011) Classification of Papulo-Squamous Skin Diseases Using Image Analysis. Skin Research and Technology, 18, 36-44. http://dx.doi.org/10.1111/j.1600-0846.2011.00511.x

[19] Del Rosso, J.Q. (2011) Adult Seborrheic Dermatitis: A Status Report on Practical Topical Management. The Journal of Clinical Aesthetic Dermatology, 4, 32-38.

[20] Kimball, A.B., Guerin, A., Tsaneva, M., Yu, A.P., Wu, E.Q., Gupta, S.R., et al. (2011) Economic Burden of Comorbidities in Patients with Psoriasis Is Substantial. Journal of the European Academy of Dermatology \& Venereology, 25, 157-163. http://dx.doi.org/10.1111/j.1468-3083.2010.03730.x

[21] Antoni, C.E., Kavanaugh, A., Kirkham, B., Tutuncu, Z., Burmester, G.R., Schneider, U., et al. (2005) Sustained Benefits of Infliximab Therapy for Dermatologic and Articular Manifestations of Psoriatic Arthritis: Results from the Infliximab Multinational Psoriatic Arthritis Controlled Trial (IMPACT). Arthritis \& Rheumatism, 52, 1227-1236. http://dx.doi.org/10.1002/art.20967

[22] Mazzotta, A., Esposito, M., Carboni, I., Schipani, C. and Chimenti, S. (2007) Clobetasol Propionate Foam 0.05\% as a Novel Topical Formulation for Plaque-Type and Scalp Psoriasis. Journal of Dermatological Treatment, 8, 84-87. http://dx.doi.org/10.1080/09546630601123835 
[23] Spandonaro, F., Altomare, G., Berardesca, E., Calzavara-Pinton, P., Chimenti, S., Girolomoni, G., et al. (2011) HealthRelated Quality of Life in Psoriasis: An Analysis of Psocare Project Patients. Giornale Italiano di Dermatologia e Venereologia, 146, 169-178.

[24] Basra, M.K., Fenech, R., Gatt, R.M., Salek, M.S. and Finlay, A.Y. (2008) The Dermatology Life Quality Index 19942007: A Comprehensive Review of Validation Data and Clinical Results. British Journal of Dermatology, 159, $997-$ 1035. http://dx.doi.org/10.1111/j.1365-2133.2008.08832.x

[25] Shikiar, R., Bresnahan, B.W., Stone, S.P., Thompson, C., Koo, J. and Revicki, D.A. (2003) Validity and Reliability of Patient Reported Outcomes Used in Psoriasis: Results from Two Randomized Clinical Trials. Health \& Quality of Life Outcomes, 1, 53. http://dx.doi.org/10.1186/1477-7525-1-53

[26] Menter, A., Gordon, K., Carey, W., Hamilton, T., Glazer, S., Caro, I., et al. (2005) Efficacy and Safety Observed during 24 Weeks of Efalizumab Therapy in Patients with Moderate to Severe Plaque Psoriasis. Archives of Dermatolology, 141, 31-38. http://dx.doi.org/10.1001/archderm.141.1.31

[27] Gottlieb, A.B., Chaudhari, U., Baker, D.G., Perate, M. and Dooley, L.T. (2003) The National Psoriasis Foundation Psoriasis Score (NPF-PS) System versus the Psoriasis Area Severity Index (PASI) and Physician's Global Assessment (PGA): A Comparison. Journal of Drugs in Dermatology, 2, 260-266.

[28] Liberati, A., Altman, D.G., Tetzlaff, J., Mulrow, C., Gøtzsche, P.C., Ioannidis, J.P., et al. (2009) The PRISMA Statement for Reporting Systematic Reviews and Meta-Analyses of Studies That Evaluate Health Care Interventions: Explanation and Elaboration. PLoS Medicine, 6, e1000100. http://dx.doi.org/10.1371/journal.pmed.1000100

[29] Sofen, H., Hudson, C.P., Cook-Bolden, F.E., Preston, N., Colón, L.E., Colón, L.E, et al. (2011) Clobetasol Propionate 0.05\% Spray for the Management of Moderate-to-Severe Plaque Psoriasis of the Scalp: Results from a Randomized Controlled Trial. Journal of Drugs in Dermatology, 10, 885-892.

[30] Olsen, E.A., Cram, D.L., Ellis, C.N., Hickman, J.G., Jacobson, C., Jenkins, E.E., et al. (1991) A Double-Blind, Vehicle-Controlled Study of Clobetasol Propionate 0.05\% (Temovate) Scalp Application in the Treatment of Moderate to Severe Scalp Psoriasis. Journal of the American Academy of Dermatology, 24, 443-447. http://dx.doi.org/10.1016/0190-9622(91)70069-E

[31] Jarratt, M., Breneman, D., Gottlieb, A.B., Poulin, Y., Liu, Y. and Foley, V. (2004) Clobetasol Propionate Shampoo 0.05\%: A New Option to Treat Patients with Moderate to Severe Scalp Psoriasis. Journal of Drugs in Dermatology, 3, 367-373.

[32] Franz, T.J., Parsell, D.A., Myers, J.A. and Hannigan, J.F. (2000) Clobetasol Propionate Foam 0.05\%: A Novel Vehicle with Enhanced Delivery. International Journal of Dermatology, 39, 535-538. http://dx.doi.org/10.1046/j.1365-4362.2000.00986-4.x

[33] Reygagne, P., Diaconu, J., Pres, H., Ernst, T.M., Meyer, K.G. and Arsonnaud, S. (2002) Efficacy and Safety Comparison of Clobetasol Propionate Shampoo, Gel and Vehicle in Scalp Psoriasis. European Academy of Dermatology and Venereology, 16, 283.

[34] Franz, T.J., Parsell, D.A., Halualani, R.M., Hannigan, J.F., Kalbach, J.P. and Harkonen, W.S. (1999) Betamethasone Valerate Foam 0.12\%: A Novel Vehicle with Enhanced Delivery and Efficacy. International Journal of Dermatolology, 38, 628-632. http://dx.doi.org/10.1046/j.1365-4362.1999.00782.x

[35] Medansky, R.S. and Handler, R.M. (1974) Treating Psoriasis of the Scalp with a New Corticosteroid Lotion. IMJ Illinois Medical Journal, 145, 503-504.

[36] Tyring, S., Mendoza, N., Appell, M., Bibby, A., Foster, R., Hamilton, T., et al. (2010) A Calcipotriene/Betamethasone Dipropionate Two-Compound Scalp Formulation in the Treatment of Scalp Psoriasis in Hispanic/Latino and Black/ African American Patients: Results of the Randomized, 8-Week, Double-Blind Phase of a Clinical Trial. International Journal of Dermatology, 49, 1328-1333. http://dx.doi.org/10.1111/j.1365-4632.2010.04598.x

[37] Harris, J.J. (1972) A National Double-Blind Clinical Trial of a New Corticosteroid Lotion: A 12-Investigator Cooperative Analysis. Current Therapeutic Research, Clinical and Experimental, 14, 638-646.

[38] Jemec, G.B., Ganslandt, C., Ortonne, J.P., Poulin, Y., Burden, A.D., de Unamuno, P., et al. (2008) A New Scalp Formulation of Calcipotriene Plus Betamethasone Compared with Its Active Ingredients and the Vehicle in the Treatment of Scalp Psoriasis: A Randomized, Double-Blind, Controlled Trial. Journal of the American Academy of Dermatology, 59, 455-463. http://dx.doi.org/10.1016/j.jaad.2008.04.027

[39] Green, C., Ganpule, M., Harris, D., Kavanagh, G., Kennedy, C., Mallett, R., et al. (1994) Comparative Effects of Calcipotriol (MC903) Solution and Placebo (Vehicle of MC903) in the Treatment of Psoriasis of the Scalp. British Journal of Dermatology, 130, 483-487. http://dx.doi.org/10.1111/j.1365-2133.1994.tb03382.x

[40] Pauporte, M., Maibach, H., Lowe, N., Pugliese, M., Friedman, D.J., Mendelsohn, H., et al. (2004) Fluocinolone Acetonide Topical Oil for Scalp Psoriasis. Journal of Dermatological Treatment, 15, 360-364.

http://dx.doi.org/10.1080/09546630410023566 
[41] Lepaw, M.I. (1978) Double-Blind Comparison of Halcinonide Solution and Placebo Control in Treatment of Psoriasis of the Scalp. Cutis, 21, 571-573.

[42] Ellis, C.N., Horwitz, S.N. and Mente, A. (1988) Amcinonide Lotion 0.1\% in the Treatment of Patients with Psoriasis of the Scalp. Current Therapeutic Research, Clinical and Experimental, 44, 315-324.

[43] Shuttleworth, D., Galloway, D.B., Boorman, G.C. and Donald, A.E. (1998) A Double-Blind, Placebo-Controlled Study of the Clinical Efficacy of Ciclopirox Olamine (1.5\%) Shampoo for the Control of Scalp Psoriasis. Journal of Dermatological Treatment, 9, 163-167. http://dx.doi.org/10.3109/09546639809160548

[44] Van Voorhees, A.S. and Fried, R. (2009) Depression and Quality of Life in Psoriasis. Postgraduate Medicine, 121, 154-161. http://dx.doi.org/10.3810/pgm.2009.07.2040

[45] Zampieron, A., Buja, A., Fusco, M., Linder, D., Bortune, M., Piaserico, S., et al. (2015) Quality of Life in Patients with Scalp Psoriasis. Giornale Italiano di Dermatolologia e Venereologia, 150, 309-316.

[46] Mrowietz, U., Macheleidt, O. and Eicke, C. (2011) Effective Treatment and Improvement of Quality of Life in Patients with Scalp Psoriasis by Topical Use of Calcipotriol/Betamethasone (Xamiol ${ }^{\circledR}-$ Gel): Results. Journal der Deutschen Dermatologischen Gesellschaft, 9, 825-831. http://dx.doi.org/10.1111/j.1610-0387.2011.07695.X

[47] Griffiths, C.E., Finlay, A.Y., Fleming, C.J., Barker, J.N., Mizzi, F. and Arsonnaud, S. (2006) A Randomized, Investigator-Masked Clinical Evaluation of the Efficacy and Safety of Clobetasol Propionate $0.05 \%$ Shampoo and Tar Blend 1\% Shampoo in the Treatment of Moderate to Severe Scalp Psoriasis. Journal of Dermatological Treatment, 17, 90-95. http://dx.doi.org/10.1080/09546630500515701

[48] Wauters, O., Roland, I. and De la Brassinne, M. (2007) Corticosteroids and Their Vehicle in the Treatment of Scalp Psoriasis. Revue Medicale de Liege, 62, 196-199.

[49] Freeman, K. (2010) The Two-Compound Formulation of Calcipotriol and Betamethasone Dipropionate for Treatment of Moderately Severe Body and Scalp Psoriasis_-An Introduction. Current Medical Research Opinion, 27, 197-203. http://dx.doi.org/10.1185/03007995.2010.540985

[50] Menter, A., Abramovits, W., Colón, L.E., Johnson, L.A. and Gottschalk, R.W. (2009) Comparing Clobetasol Propionate $0.05 \%$ Spray to Calcipotriene $0.005 \%$ Betamethasone Dipropionate $0.064 \%$ Ointment for the Treatment of Moderate to Severe Plaque Psoriasis. Journal of Drugs in Dermatolology, 8, 52-57.

[51] Meredith, F. and Ormerod, A.D. (2012) Patient Preferences for Psoriasis Treatment: Process Characteristics Considered More Important than Outcome Attributes. Expert Review of Pharmacoeconomics \& Outcomes Research, 12, 145-147. http://dx.doi.org/10.1586/erp.12.9

[52] Nast, A., Boehncke, W.H., Mrowietz, U., Ockenfels, H.M., Philipp, S., Reich, K., et al. (2012) Deutsche Dermatologische Gesellschaft (DDG); Berufsverband Deutscher Dermatologen (BVDD). S3-Guidelines on the Treatment of Psoriasis Vulgaris (English Version). Update. Journal der Deutschen Dermatologischen Gesellschaft, 10, S1-S95. http://dx.doi.org/10.1111/j.1610-0387.2012.07919.x

[53] Kortuem, K.R., Davis, M.D., Witman, P.M., McEvoy, M.T. and Farmer, S.A. (2010) Results of Goeckerman Treatment for Psoriasis in Children: A 21-Year Retrospective Review. Pediatric Dermatology, 27, 518-524. http://dx.doi.org/10.1111/j.1525-1470.2010.01124.x

[54] Carretero, G., Puig, L., Dehesa, L., Carrascosa, J.M., Ribera, M., Sánchez-Regaña, M., et al. (2010) Metotrexato: Guía de uso en psoriasis (Guidelines on the Use of Methotrexate in Psoriasis). Actas Dermo-Sifiliográficas, 101, 600-613. http://dx.doi.org/10.1016/j.ad.2010.04.002

[55] Due, E., Blomberg, M., Skov, L. and Zachariae, C. (2011) Discontinuation of Methotrexate in Psoriasis. Acta Dermato Venereologica, 92, 353-354. http://dx.doi.org/10.2340/00015555-1233

[56] Vergou, T., Moustou, A.E., Sfikakis, P.P., Antoniou, C. and Stratigos, A.J. (2011) Pharmacodynamics of TNF- $\alpha$ Inhibitors in Psoriasis. Expert Review of Clinical Pharmacology, 4, 515-523. http://dx.doi.org/10.1586/ecp.11.28

[57] Gordon, K., Papp, K., Poulin, Y., Gu, Y., Rozzo, S. and Sasso, E.H. (2012) Long-Term Efficacy and Safety of Adalimumab in Patients with Moderate to Severe Psoriasis Treated Continuously over 3 Years: Results from an Open-Label Extension Study for Patients from REVEAL. Journal of the American Academy of Dermatology, 66, 241-251. http://dx.doi.org/10.1016/j.jaad.2010.12.005

[58] Kimball, A.B., Jacobson, C., Weiss, S., Vreeland, M.G. and Wu, Y. (2005) The Psychosocial Burden of Psoriasis. American Journal of Clinical Dermatology, 6, 383-392. http://dx.doi.org/10.2165/00128071-200506060-00005

[59] Kurd, S.K., Troxel, A.B., Crits-Christoph, P. and Gelfand, J.M. (2010) The Risk of Depression, Anxiety, and Suicidally in Patients with Psoriasis: A Population-Based Cohort Study. Archives of Dermatology, 146, 891-895.

[60] Gupta, M.A., Schork, N.J., Gupta, A.K., Kirkby, S. and Ellis, C.N. (1993) Suicidal Ideation in Psoriasis. International Journal of Dermatology, 32, 188-190. http://dx.doi.org/10.1111/j.1365-4362.1993.tb02790.x 